\title{
Production of Rice in Nigeria: The Role of Indian-Nigerian Bilateral Cooperation in Food Security
}

\author{
Lucky lgohosa Ugbudian \\ Alex Ekwueme Federal University, Ndufu-Alike
}

\begin{abstract}
The article focuses on the impact of India-Nigeria agricultural cooperation on rice production in Nigeria. Since 2000 in the quest for food sufficiency, diversification of the country's sources of foreign exchange, increasing employment for the rising population as well as expanding its external relations Nigeria has signed several bilateral agreements on agriculture with India. The analysis of the developments in the sub-sector, as well as media, governmental and non-governmental reports in the field and the interviews of the farmers has revealed that the Indian firms, including "Olam Group" and "Popular Farms and Mills Ltd", have cultivated thousands of hectares of land, built mills and machinery, provided farmers in 16 Nigerian states with better rice seedlings, and engaged thousands of farmers in regular training improving employment and revitalizing communities in the country. The support given by the Indian firms has triggered an unprecedented increase in rice production. The paper concludes that the agreements, particularly the one of 2017, have further promoted, strengthened and expanded rice production in the context of food security, job creation and saving foreign exchange. The article, therefore, demonstrates how Nigeria-India bilateral ties and cooperative programs have changed the dynamics of rice production in the country and brought more profound economic consequences. Despite the fact that Nigeria is not yet selfsufficient in rice production with the gap of around 2.5 million tonnes, the agricultural programs initiated within the framework of the Nigeria-India bilateral agreements and realized as large-scale agriculture programmes including investments, training, supply of better seedlings, land cultivation promoted by powerful corporations have significantly changed the economic and social environment in Nigeria.
\end{abstract}

Key words: Rice Production, Nigeria, India, Bilateral Agreements, Food Sufficiency 
7 he apparent deficit in rice production with attendant burden and pressures on scarce resources forced the Nigerian government to engage with India. This culminated in several bilateral agreements on agriculture and trade. The key aspects of cooperation have been the encouragement of the major Indian corporations to participate in local rice production in Nigeria.

The role of bilateral cooperation in revamping and reconstructing the main sectors of the country's economy cannot be overemphasized. Since 1960, when the state gained independence, Nigeria has been cementing ties with several countries covering political, socio-cultural, scientific, economic as well as health spheres. It was in this spirit that the Nigerian government maintain warm relations with India which have culminated in a series of bilateral agreements concerning different sectors including education and agriculture. The decay of the Nigerian agricultural sector, however, had a negative effect on rice production in the country. That became obvious in the mid-1970's when the country lost self-sufficiency in local production and resorted to import. By early 1980's the import of rice reached an alarming scale that led to the imposition of restrictions and more governmental subsidies to local producers through international institutional supports. The administration of Goodluck Jonathan, tackling the problem of unsustainable rice import bill and its impact on foreign exchange earnings, decided to sign a new bilateral agricultural agreement with the Indian government. This bold step has gradually revitalized the rice production in the country: the agreement, guaranteeing safety and stability, motivated Indian companies to invest millions of dollars in rice farming and milling factories. The article, therefore, demonstrates the role of Nigeria-Indian bilateral cooperation in revamping the local production of rice in the country.

\section{Conceptual framework}

Nigeria is a vast agricultural country endowed with natural resources which include 68 million hectares of arable land, freshwater resources covering about 12 million hectares, 960 kilometres of coastline and ecological diversity which enables the country to produce a wide variety of crops and livestock, forestry and fisheries products (Oyakhilomen, Zibah 2014). Agriculture has to do with the cultivation of varieties of crop and creates value chain processes, and it's development usually has a multiplier effects on economy, people welfare and, moreover, state security.

The significance of agriculture for the Nigerian population cannot be overemphasized because it employs over 80 percent of the workforce, provides food, increases household incomes, local foreign exchange earnings and improves standards of living particularly of rural farmers.

Agriculture provided for a greater part of the economic growth and development in Nigeria between the 1950's and 1960's; however, it dropped drastically following the discovering of crude oil in the country that in turn added 1,342 million naira to the GDP in 1958/1959, and 1,808 million naira in 1973-1974 (Izuchukwu 2011). In the 
2000's the Nigerian government in an attempt to reverse the decline in agriculture developed an economic framework named "The Economic Recovery and Growth Plan" (ERGP). The ERGP is an all-round developmental initiative covering 2017 to 2020 and including the "Strategic Implementation Plan" with an objective to restore economic growth and development ${ }^{1}$. The major goals of the ERGP are investing in human resources, building a competitive economy and raising the annual growth of GDP to 7 percent (Izuchukwu 2011). The key point of the plan is stabilization of macroeconomic and economic diversification, development of agriculture, energy, Micro, Small and Medium-scale enterprises (MSME), growth in industry, manufacturing and key services by leveraging science and technology. This has led to more investments in the agricultural sector, financial, technological and educational support to the farmers and entrepreneurs. Agriculture has experienced increased production, employment and served as a basis for the other sectors according to the recent report of the National Bureau of Statistics ${ }^{2}$.

As for the concept of food security, although defined differently by scholars and international organizations it usually embraces the availability, accessibility, utilization and stability of food for citizens in a given period and on a regular basis. Moreover, some experts include also such a category as a relevant nutritious and added value. The first major attempt to define "food security" could be traced back to 1905 when the Italian government sponsored the first conference of the International Institute of Agriculture ${ }^{3}$. This laid the ground for the formation of the Food and Agriculture Organization (FAO) which is now a leading global institution in proposing solutions to the issues of food security, elimination of hunger and agricultural development. These efforts culminated in the World Food Summit in 1974 conceiving food security as the availability at all times of adequate world food supplies of basic foodstuffs to sustain a steady expansion of food consumption and to offset fluctuations in production and prices. This definition is narrow and failed to cover the essential aspect of the quality of the food. Poor conceptualization led the Food and Agricultural Organisation (1983) to suggest that food security should include ensuring that all people at all times have both physical and economic access to the basic food that they need. However, the quality of food was not taken into account. At the same time, the World Bank Report of 1986 dwelled on the existence of trends in food security arguing that food security must result in access of all people at all times to enough food for an active, healthy life ${ }^{4}$.

\footnotetext{
1 The Economic Recovery and Growth Plan. 2017. Nigerian Investment Promotion Commission. URL: https://nipc.gov.ng/ product/nigerias-economic-recovery-and-growth-plan-ergp-for-2017-2020/ (accessed 26.06.2020)

2 Social Statistics in Nigeria: Employment Data. 2015. Abuja NBS Press. URL: https://www.nigerianstat.gov.ng (accessed 26.06.2020)

3 Food and Agricultural Organization of the United Nations, History. URL: http://www.fao.org/home/en/ (accessed 26.06.2020)

${ }_{4}$ Poverty and Hunger: Issues and Options for Food Security in Developing Countries. 1986. World Bank. Washington DC. URL: http://documents.worldbank.org/curated/en/166331467990005748/Poverty-and-hunger-issues-and-optionsfor-food-security-in-developing-countries (accessed 26.06.2020)
} 
The report highlighted a wide gap between chronic food insecurity, associated with problems of structural poverty and low incomes, and transitory food insecurity, which involved periods of intensified pressure caused by natural disasters, economic collapse or conflict. The UNDP Human Development Report of 1994 included in food security the provision of food in quantity and quality for human". "The State of Food Insecurity" (2001) complemented the definition of the UNDP and defined it as a situation that exists when all people, at all times, have physical, social and economic access to sufficient, safe and nutritious food that meets their dietary needs and food preferences for an active and healthy life ${ }^{6}$.

Amid this conceptual development the FAO designed and implemented a number of programs to alleviate food insecurity. The recent program fashioned to contribute to the Sustainable Development Goals (SDGs) deals with "Zero Hunger" for the global population ${ }^{7}$.

Food security is critical to national growth and development. The lack of it often makes a country rely on import at a huge cost. Most countries with poor self-sufficiency such as Nigeria usually depend on import even to feed their population. Over the years Nigeria was able to meet the food needs of its people because the majority of population engaged in agricultural production and until the 1970's the sector was supported by government policies and plans. The reliance on crude oil, lack of investment, drought and famine made the agricultural sector unattractive. Rising population and changing consumption patterns aggravated the crisis coupled by unprecedented ruralurban migration. It resulted in a shift to the consumption of rice as a staple food in the 1970's following the oil boom. The demand for rice increased geometrically while the production grew arithmetically, hence, deepening state's dependence on import. The production gap created food insecurity, especially among the most vulnerable, namely the poor, children and women.

Bilateral cooperation was considered to be a key to the problem. Geoff R. Berridge's conception of bilateralism covers the process when two international actors negotiate and cooperate while pursuing their national interests (Berridge 1995). Alexander Thompson conceives bilateralism as the interaction of independent states on issues pertaining to the welfare of their people and countries that might be sociocultural, political or economic (Thompson 2014). The spirit and letter of bilateralism often make states to recognize each other and result in the exchange of diplomatic missions to strengthen the relations. Similarly, states could also decide to complement, sustain and promote comparative advantage by engaging in trade agreements for economic growth and development.

\footnotetext{
${ }_{5}^{5}$ Human Development Report of 1994. 1994. Published for the United Nations Development Programme (UNDP). URL: http://hdr.undp.org/sites/default/files/reports/255/hdr_1994_en_complete_nostats.pdf (accessed 26.06.2020)

6 The State of Food Insecurity in the World 2001. Food and Agricultural Organization of the United Nations, History. URL: http://www.fao.org/3/y1500e/y1500e01.htm\#P0_0 (accessed 26.06.2020)

7 Towards Zero Hunger 1945-2030. Food and Agriculture Organization of the United Nations. URL: http://www.fao.org/3/ai6196e.pdf (accessed 26.06.2020)
} 


\section{Nigeria and Indian bilateral cooperation}

The relations between Nigeria and India have always been peaceful and friendly even before the former gained independence in 1960, with India establishing its consulate in Nigeria in 1958. Later Nigeria had been further strengthening ties with India in the political, security, socio-cultural and economic spheres. These warm relations also reflected in sharing the same position at the international stage; for instance, the both joined the Non-Aligned Movement (NAM) during the Cold War. The economic ties, however, remained weak between 1960's and 1998, but received a tremendous boost following the return of democratic governance in Nigeria in 1999. It resulted in exchange of visits by the leaders of both countries and the endorsement of agreements aimed at increasing trade between them. In 2003 for the first time President Olusegun Obasanjo reciprocated the visit of Prime Minister Pundit Jawaharlal Nehru to Nigeria in September 1962. At the same time, top Indian officials including Prime Ministers Dr. Manmohan Singh and Narendra Modi visited Nigeria in 2005 and 2017 respectively. The volume of trade reached its peak at $\$ 19.5$ billion in 2014 before dropping to \$16.36 in 2015 (Akpokodje et al. 2001).

One of the major agreements, "The Strategic Partnership Agreement", was signed in 2007, and included the Memorandum of understanding between the Foreign Service Institute and the Nigerian Foreign Service Academy, the Memorandum of understanding between the Indian Council for World Affairs (ICWA) and the Nigerian Institute of International Affairs, Protocol for Foreign Office Consultations and the Memorandum of understanding on Defence Cooperation. The 2017 bilateral agreement deals specifically with civil aviation and agriculture. While the first venue makes provision for a direct air links between both countries, the second one dwells on enhancing food security and self-sufficiency in rice production. It should be noted that the major objectives of these agreements were the promotion and protection of food security for Nigerians. Therefore, the quest for sustainable agricultural development in Nigeria relies on the bilateral agreements with India one of the closest partners that have been establishing companies and investing in the Nigerian economy. Some of these companies were involved in the importation of agro-products especially rice to the country from India and elsewhere.

The food industry generally includes legumes (groundnut, cowpeas and other vegetables), cereals (sorghum, maize, wheat, rice and millet), and tubers (yam, cassava and others). The dynamic of the rice food subsector in the last decade reflects the renewed and determined efforts of the Nigerian leaders to meet the consumption needs of the people. Since 1970's Nigerians began to consume rice on an unprecedented scale: annually rice consumption has been rising by not less than 10 percent, gradually putting more pressure on domestic agriculture that culminated in the demand for importation to complement the local production which got to 372000 metric tonnes per annum by 1979 . At the same time its deficit rose to 1000000 metric tonnes annually between the late 1980's and 1990's following the embargo on importation. While the production 
was in the hands of small landholders, largely in the rural agro-ecological zones, the importation was driven by military regime to their "cronies". By the first decade of the 21 st century the worsened rice cultivation, which was less than $6.4 \%$ from more than 25 million hectares of land, coupled with the removal of import restrictions as well as the unmet local demand, has led to the importation of millions of metric tonnes with the cost of 259 million USD. The lack of investments in the local rice production and rising consumption by Nigerians further deepened the deficits to about 4 million metric tonnes costing over 300 million USD (Akpokodje et al. 2001). This alarming rate of import made the President Jonathan's administration use the Nigeria-India bilateral agreements to reverse the trend by using the Indian experience in rice production and running the big agricultural corporations.

The map (see Picture 1) shows the rice producing states in Nigeria. There are two major corporations controlled by Indians: "Olam Group" operates mainly in Nasarawa, Niger and Taraba states while "Popular Farms and Mills Limited" areas of operations spans 16 states including Kano, Kaduna, Yobe, Kebbi, Katsina, Abuja, Nigeria, Benue, Taraba, and Borno.

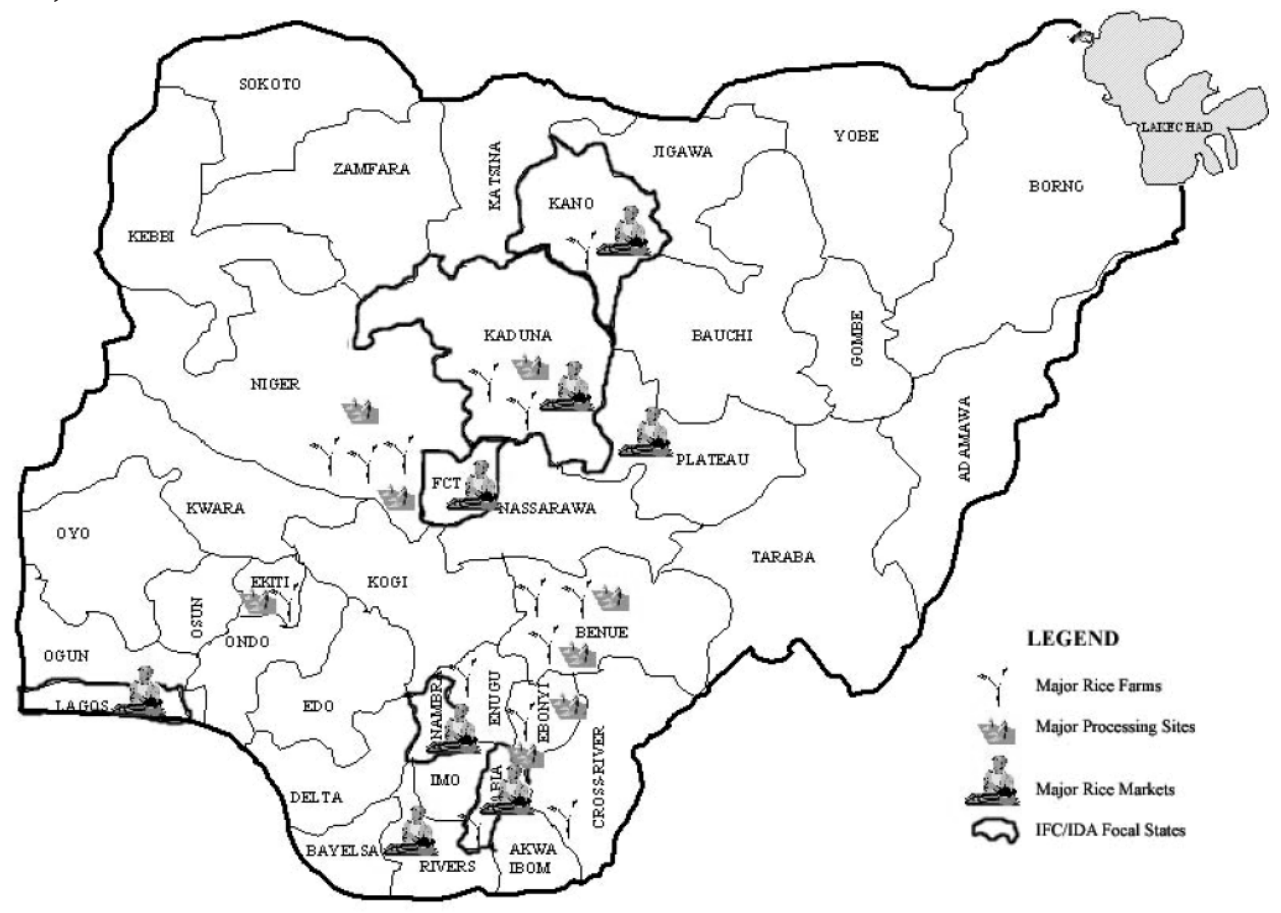

Picture 1. Rice producing states in Nigeria

Source: (Phillip et al. 2009)

\section{The impact of bilateral cooperation on rice production}

The paradigm shift of the Nigerian government from importation to transforming local rice production was impeded by several factors such as the lack of mecha- 
nized rice farming and equipment, aging farmers and low-yielding seedlings and pests. The administration of Goodluck Jonathan mobilized and encouraged individuals and organizations to support rice production. Consequently, the government exploited investments and bilateral ties between Nigeria and India to encourage more Indian entities and companies to invest more in the rice sub-sector. It should be noted that Indians have always been interested in broader integration with the major companies involved in rice importation, namely "Olam Limited" and "Stallion Group". These partnerships included provision and equipment of rice mill factories, supplying high-yielding seedlings and acquisition of several hectares of land for cultivation of rice.

The Table 1 summarises the volume of trade between Nigeria and India since 2012. The available statistics reveals that there was an upsurge in trade until Nigeria faced economic recession in 2015 resulted in weakened local currency. While crude oil became the major export category from Nigeria to India, India exported machineries and equipment, among the others, for the agro-sectors.

Table 1. India-Nigeria bilateral trade statistics (US \$ billions)

\begin{tabular}{|c|c|c|c|c|c|}
\hline & $2012-2013$ & $2013-2014$ & $2014-2015$ & $2015-2016$ & $2016-2017$ \\
\hline Indian's import & 13826 & 14098.38 & 13682.72 & 9949.16 & 7659 \\
\hline Indian's export & 2738 & 2667.33 & 2681.36 & 2222.0 & 1771.33 \\
\hline
\end{tabular}

The "Stallion Group" conglomerate with the Nigerian headquarters in Kano and other parts of the country established its agribusiness subsidiary, "Popular Farm and Mills Lmtd", shifting its focus from importation to local rice production, training farmers and distributing seedlings in every planting season in all parts of the country. For instance, in 2017 the company distributed not less than 100 bags of the rice seedlings to farmers in Yola, Adamawa state.

According to Pandian Balamurugun, the director of the company, such an activity was in the spirit of the bilateral agricultural cooperation between Nigeria and India. He stated that the main objective of the gesture was to build a solid agricultural cooperation between India and Nigeria and to assist rice farmers in the country to boost their local rice production. The initiative was aimed not only at reducing the burden of rice importation but also eliminating poverty among rural farmers as well as attracting youth to the agricultural business. He supposed that the company had been collaborating and supporting rice farmers as well as farmers' cooperatives to increase rice production. This resulted in the company supporting more than 5000 farmers in 16 states of the country. At the same time, the company inaugurated "a unit to procure farm product direct from the farmers at affordable prices, to enhance their income generation"s. It must be noted that the company promoted its rice brands

\footnotetext{
8 Pandian Balamurugun, Director, Popular Farm and Limited, interviewed by the author in Taraba on November 23, 2017.
} 
during "the Kano Rice Fair" in 2015 which included "Royal Stallion Shinkafa" and "Super Champion" which received widespread acceptance by the people that attended the fair. Pandian Balamurugun believes that his firm's backward integration was initiated in 2011 as a part of the Nigeria-Indian bilateral cooperation on agriculture and put in place a number of measures such as the construction of factories and millings and delivering better seedlings. To him this effort over the years lifted thousands of Nigerian rice farmers out of poverty and created hundreds of thousands of jobs in the related areas. The obstacles to the effective rice production, in his view, remain the same: poor network of roads and logistics that in turn affects the marketing and prices of the product ${ }^{9}$.

One of the objectives of the fair, facilitated by "The Growth and Employment" in States (GEMS4) Project was to enhance market penetration of the Nigeria-made rice. This position was supported by "Stallion Group" General Manager Amit Kumar, who stated: "We would appreciate more of these kinds of outings to help boost and sustain rice production, increase awareness and ultimately advance the patronage of Nigerian rice brands. We are soon going to launch new, more nutritious and highly competitive brands in the near future. The company's impressive performance at the Rice fair was informed by its unequalled footprint and vast investment in agriculture. Popular Farms \& Mills' approach towards the backward integration of the Rice Value Chain is based on the simple mission of strengthening the rice farming and farming community. Its unique approach towards cooperatives integration by the means of technical knowledge transmission, assimilation of efficient farming mechanism to give higher yield and make farming profitable for the community is spread across rice producing states of Nigeria. Thousands of farmers and farmers cooperatives have become partners in the Stallion Group's Mission of Leading Nigerian Rice Revolution through its backward integration initiatives. Group Farmer Agric Centers across rice producing states have become nodal centre of all such initiatives including off taking locally produced paddy"10.

The Group's Director of “The Popular Farm Limited” Harpreet Singh further emphasised the importance of food security and self-sufficiency in rice production arguing that sensing the need for local self-sufficiency and government's ambitions for food security, Stallion pioneered investments into backward integration, creating a fully integrated value chain. "We are working tirelessly to improve farm yields and bring in sustainable and scalable growth to farmers" (Oyakhilomen, Zibah 2014). Their company, implementing and strengthening backward integration, supported local manufacturing facilities for nation-wide distribution infrastructure designed to meet the demands of the Nigerian people. The company, therefore, established new services known as "Village School" charged with the responsibility of training and distributing machineries and interfacing with farmers cooperatives to promote agricultural revolu-

\footnotetext{
9 Ibid.

${ }^{10}$ Agro-Nigeria 2015. URL: https://www.agronigeria.com.ng/stallion-group-new-realities-in-the-nigerian-rice-industry/ (accessed 26.06.2020)
} 
tion in the country. In this regard, "Popular Farm" set up many collection points located in different parts of the rice producing states, namely Taraba, Benue, Adamawa, Niger, Kaduna, Kano, Jigawa, Sokoto, Kebbi and Zamfara ${ }^{11}$.

In the interview, Garba Mohammed, a rice farmer in Kano, expresses satisfaction with the annual support "The Popular Farms and Mills Limited", a subsidiary of "Stallion Group" provides him with ${ }^{12}$. This assistance, according to him, includes not only training and supply of better yielding seedlings, but also buying his products. Another rice farmer in the Kaduna state Umar Abbani also states that rice farming has increasingly become a booming and lucrative business ${ }^{13}$. Garba Mohammed says that now farmers are making real profits in rice farming and improving the farms. He adds that "Popular Farms and Mills Limited" has been supportive of his farming venture through the provision of a number of incentives thereby motivating him to cultivate more acres of land and revitalise farmer cooperatives. In his words, the efforts of "Popular Farms and Mills Limited" encouraged rice professional associations to help farmers benefit more from the business. The company also gives support in form of seedlings, financial and training for improved production ${ }^{14}$. One of the farmers in Niger state Abdullahi Sani explains the role of the government in the ongoing transformations. To him, while the federal government through the CBN Anchor Borrower scheme assists farmers with soft loans, the "Stallion Group" support is much broader. Training and seedling supply by the company appears to be helpful to have a higher yield and using more acres of land expanded the farm for him and his children ${ }^{15}$. Murtala Usman says that the "Stallion Group" has created thousands of jobs in the state not to mention the direct support to the farmers ${ }^{16}$.

"Olam Group", a multinational organisation with huge Indian share, commenced rice production in 2011, investing 25 billion naira. The Olam produced new rice brands for the Nigerian market including famous "Mama's Pride" and "Mama's Choice". By 2013, the company cultivated 10000 hectares of land, constructed mills and invested more than 19 billion naira. In addition, the company employed more than 950 workers and produced 36000 metric tonnes of rice in 2011. The company expanded cultivation to 4450 out of 9479 hectares thereby hiring 1044 regular and 450 seasonal farmers in 2017. The seedling varieties, according to "The West African Rice Development Association", are expected to yield 10 metric tonnes per hectare over two crop cycles. In 2014 the corporation distributed high-yielding seedlings to 888 farmers, engaged 16000 farmers in the outgrower scheme in 2018 supplying not less than 40 percent of the rice mills capacity and integrated the 120 million USD rice farm and the mill

\footnotetext{
${ }^{11}$ Falade D. 2017. Stallion Group Targets 1.5m Tonnes Annual Rice Production. Nigerian Tribune. March 27. URL: https:// tribuneonlineng.com/bags-ibca-outstanding-projects-business-leader-awards/ (accessed 26.06.2020)

12 Garba Mohammed, rice farmer, 54, interviewed by the author in Kano in November 2017.

${ }^{13}$ Umar Abbani, rice farmer, 50, interviewed by the author in Kaduna on November 24, 2017.

${ }^{14}$ Garba Mohammed, rice farmer, 54, interviewed by the author in Kano in November 2017.

15 Abdullahi Sani, rice farmer, 53, interviewed by the author in Kano on November, 252017.

${ }^{16}$ Murtala Usman, rice farmer, 45, interviewed by the author in Kano on November, 252017.
} 
in Ondorie, Nasarawa State ${ }^{17}$. The annual production of rice by the "Olam Group" has gradually increased from over 100000 metric tonnes in 2013 to over 420000 metric tonnes in 2016-2017 farm season ${ }^{18}$.

Mahesh Nimje, the Officer in-charge of the project in "Olam", explained that the company continues to be highly involved in contributing to the rice self-sufficiency. He argues that the current rice demand in the country is about 6 million metric tonnes while the supply is 3.5 million $^{19}$. If the activity of the corporations including those initiated within the framework of India-Nigeria cooperation, like "Olam Group", and foreign investment increase, Nigeria is sure to become a self-sufficient state in rice production in the short term. He concludes that government needs to broaden access to financial resources for farmers and encourage foreign direct investment especially in agriculture. It also has to improve infrastructural environment since there is lack of electricity and poor facilities as well as bad roads network for the transportation of rice - everything rising its price.

One of the rice farmers that benefits from the support offered Mary John points out that rice farming has become a "big business" due to the incentives and training provided by the Group especially while the Central Bank of Nigeria gives low-interest loans ${ }^{20}$.

Transformations in agriculture are accompanied by further social changes. Farmer Ruth Amos claims that despite having extra hours at the "Olam", she is now able to pay school fees for her kids ${ }^{21}$. The interviews of rice farmers benefiting from the supportive programs shows that the majority of them consider the company to be an agent of a historical change that is improving social and economic stance in Nigeria lifting the thousands out of poverty. This explains the mass support for the "Olam Group" and "Popular Farms and Mills Limited".

To demonstrate the rising contribution to the local rice production in the country, one of the major companies in the subsector, "Popular Farms and Mills Limited" of "Stallion Group" was awarded "the Outstanding Projects and Business Leader Award" in 2017 at the IBCA Programme in Lagos. The award was in recognition of the resolute efforts of the organisation in strengthening Nigeria's self-sufficiency in rice by integrating rice value chain in food production ${ }^{22}$. On the other hand, "The National Productivity Centre" awarded "Olam Group" in 2016 for its contribution to rice production in Nigeria with the aim of bridging the Nigeria rice gap.

\footnotetext{
${ }_{17}$ Blueprint: Olam farm targets 40000 Tonnes of Paddy Rice by 2017. URL: https://blueprint.ng/olam-sfarm-targets-40000tonnes-of-paddy-rice-by-2017/ (accessed 26.06.2020)

18 Yusuf V.A. Olam Nigeria Gets Productivity Award for Rice Production. Daily Trust. March 9, 2017. URL: https://www. dailytrust.com.ng/olam-nigeria-gets-productivity-award-for-rice-production.html (accessed 26.06.2020)

${ }^{19}$ Mahesh Nimje, Project Officer, Olam, interviewed by the author in Kano on November 26, 2017.

${ }^{20}$ Mary John, rice farmer, 46, interviewed by the author in Taraba on November 22, 2017.

${ }^{21}$ Ruth Amos, rice farmer, 41, interviewed by the author in Nasarawa on November 23, 2017.

22 Stallion to Boost Rice Production to 1.5 Million Tonnes Annually. The Nation Newspaper. 14 May 2017. (accessed 26.06.2020)
} 
Fig. 1 shows that since 2014 there has been a substantial and progressive increase in rice production in the country driven partly by the contribution of the Indianowned and supported companies in the spirit of the bilateral cooperation. The two major Indian companies have a combined rice production of almost 1 million metric tonnes annually and are planning to increase it to 3 million metric tonnes ${ }^{23}$.

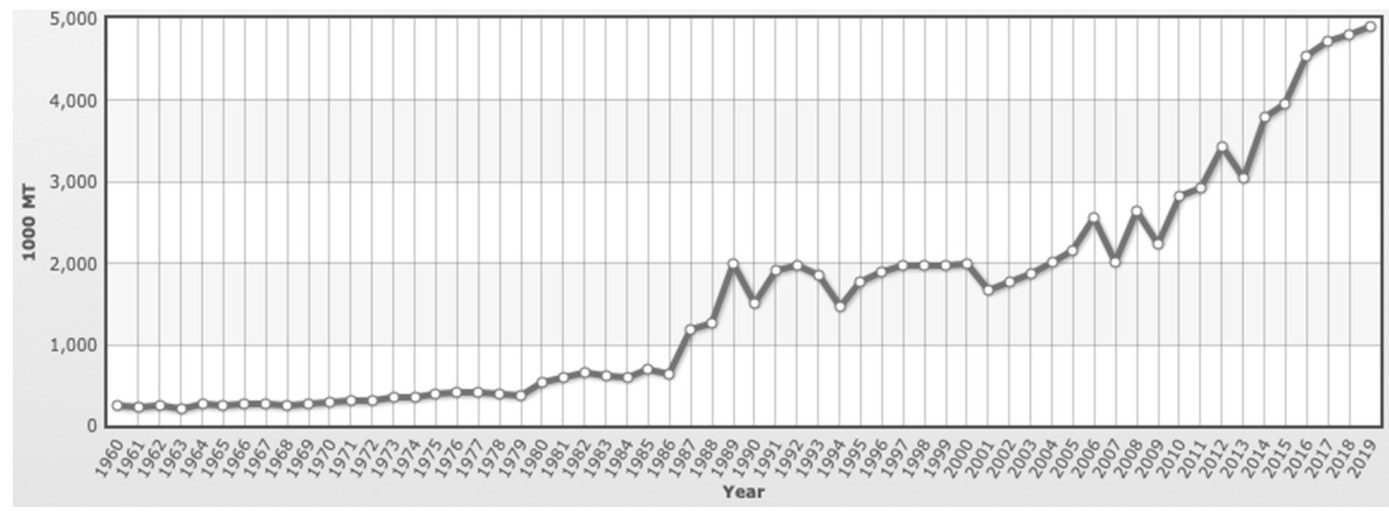

Figure 1. Nigeria rice production by year

Source: Index Mundi. Milled Rice. URL: https://www.indexmundi.com/agriculture/?c ountry=ng\&commodity=milled-rice\&graph=production $($ accessed 20.06 .2020$)$

Table 2 summarises the number of jobs each company has created since 2013 as well as the number of farmers supported by them.

Table 2. Support to farmers and job creation by the two leading corporations

\begin{tabular}{|c|c|c|c|c|}
\hline Year & $\begin{array}{c}\text { "Popular Farms and Mills } \\
\text { Limited": number of farmers } \\
\text { employed - permanent/ Casual }\end{array}$ & $\begin{array}{c}\text { "Olam Rice": number } \\
\text { of farmers employed } \\
\text { - permanent/ Casual }\end{array}$ & $\begin{array}{c}\text { "Popular Farms and } \\
\text { Mills Limited": sup- } \\
\text { ported rice farmers }\end{array}$ & $\begin{array}{c}\text { "Olam Rice": sup- } \\
\text { ported rice farmers }\end{array}$ \\
\hline 2013 & 1000 & 950 & 2550 & 1955 \\
\hline 2014 & 1050 & 972 & 3800 & 2320 \\
\hline 2015 & 2500 & 1954 & 4120 & 3500 \\
\hline 2016 & 3600 & 3500 & 5000 & 4000 \\
\hline
\end{tabular}

Source: Field research of the author; Federal Ministry of Agricultural and Rural Development. URL: https://fmard.gov.ng (accessed 12.12.2019)

The statistics shows that deepening bilateral cooperation between Nigeria and India have positive and multiplier effects on Nigerian food security, economic development, employment and welfare. Nigerian Minister of Agriculture Audu Ogbeh highlighted the efforts of the companies taken part in bilateral programs as critical for the state development ${ }^{24}$.

\footnotetext{
${ }^{23}$ Olam Farm Targets 40000 Tonnes of Paddy Rice by 2017. Blueprint. URL: https://blueprint.ng/olam-sfarm-targets-40000tonnes-of-paddy-rice-by-2017/ (accessed 26.06.2020)

${ }^{24}$ Yusuf V.A. Olam Nigeria Gets Productivity Award for Rice Production. Daily Trust. March 9, 2017. URL: https://www. dailytrust.com.ng/olam-nigeria-gets-productivity-award-for-rice-production.html (accessed (accessed 26.06.2020)
} 
The article, therefore, demonstrates how Nigeria-India cooperative programs have changed the dynamics of rice production in the country and brought more profound economic consequences. What is more, the role of the Indian corporations cannot be overemphasized. Despite the fact that Nigeria is not yet self-sufficient in rice production with the gap of around 2.5 million tonnes, the agricultural programs initiated within the framework of the Nigeria-India bilateral agreements and realized as largescale agriculture programmes including investments, training, supply of better seedlings, land cultivation promoted by powerful corporations have significantly improved the economic and social environment in Nigeria.

\title{
About the author:
}

Lucky Igohosa Ugbudian - PhD, Department of History and Strategic Studies, Faculty of Humanities, Alex Ekwueme Federal University, Ndufu-Alike. Ikwo, Abakaliki, Ebonyi State, Nigeria.

E-mail: liugbudian@gmail.com

Conflict of interests: The author declares absence of conflict of interests.

\section{Производство риса в Нигерии: роль} индийско-нигерийского двустороннего сотрудничества в обеспечении продовольственной безопасности

\author{
Луки Игохоса Угбудиан \\ DOI 10.24833/2071-8160-2020-3-72-138-150 \\ Федеральный университет имени Алекса Эквуема, Нигерия
}

В статье рассматривается влияние двустороннего сотрудничества Индии и Нигерии в области сельского хозяйства на производство ключевой культуры в Нигерии - риса. С 2000 г., стремясь обеспечить продовольственную безопасность, диверсифицировать источники иностранных инвестиций, увеличить занятость среди увеличивающегося населения, а также расширить свои внешние связи, Нигерия подписала несколько двусторонних соглашений в сфере сельского хозяйства с Индией. На основе анализа развития этого стратегически важного для экономики страны сектора, а также исследования публикаций в средствах массовой информации, докладов правительственных и неправительственных структур и на основе интервьюирования нигерийских фермеров удалось обнаружить, что усилиями индийских корпораций, в том числе Olam Group u Popular Farms and Mills Ltd, было обрабо- 
тано несколько тысяч гектаров земли, построены мельницы и ввезено оборудование, фермеры в 16 штатах были обеспечены более плодоносными сортами риса, приняли участие в обучении и нашли рабочие места. Поддержка, оказанная индийскими компаниями, способствовала беспрецедентному увеличению производства риса в стране. В статье делается вывод о том, что двусторонние соглашения, в частности соглашение 2017 г., содействовали дальнейшему развитию, укреплению и расширению производства риса в контексте продовольственной безопасности Нигерии. Автор показывает, как двусторонние связи и программы сотрудничества Нигерии и Индии изменили динамику производства риса в стране и привели к более глубоким экономическим последствиям. Несмотря на тот факт, что Нигерия всё ещё не может полностью обеспечить себя достаточным урожаем риса, сельскохозяйственные программы, запущенные в рамках двусторонних соглашений и реализованные в виде крупномасштабных сельскохозяйственных программ, включавших инвестиции, обучение, поставку лучших сортов, возделывание земель и поддержанные влиятельными корпорациями, значительно изменили социально-экономическую ситуацию в Нигерии.

Ключевые слова: производство риса, Нигерия, Индия, двустороннее сотрудничество, продовольственная безопасность

\section{O6 авmоре:}

Луки Игохоса Угбудиан - PhD, Департамент истории и стратегических исследований, Факультет гуманитарных наук, Department of History and Strategic Studies, Faculty of Humanities, Федеральный университет им. Алекса Эквуэме. Айкво, Абакалика, Эбони, Нигерия. E-mail: liugbudian@gmail.com

Конфликт интересов: Автор заявляет об отсутствии конфликта интересов.

\section{References:}

Akpokodje G., Lancon F., Erenstein O. 2001. Nigerian Rice Economy: State of the Art. The Nigerian Rice Economy in a Competitive World: Constraints, Opportunities and Strategic Choices. West Africa Rice Development Association (WARDA). Bouake, Côte d'Ivoire. P. 1-57. $212 \mathrm{p}$.

Berridge G.R. 1995. Diplomacy: Theory and Practice. Prentice Hall. Harvester Wheatsheaf.

Gujarati D.N. 2007. Basic Econometrics. $4^{\text {th }}$ Edition. Tata McGraw-Hill, New Delhi.

Izuchukwu O. 2011. Analysis of the Contributions of Agricultural Sector on the Nigerian Economic Development. World Review of Business Research. №1. P. 191-200.

Jhingan M.L. 2010. The Economics of Development and Planning (39 ${ }^{\text {th }}$ edn). Vrinda Publication (P) Ltd.

Maxwell S. 1996. Food Security: A Post-Modern Perspective. Food Policy. №2. P. 155-170.

Nwachukwu I.M., Agwu N.M., Ezeh C.I. 2008. Comparative Study of Consumer Purchase Attitude of Local and Foreign Rice in Abia State. Proceedings of $42^{\text {nd }}$ Meeting of Agricultural Society of Nigeria Held at Ebonyi State University, Abakaliki, 19-23 October. P. 764-767.

Oyakhilomen O., Zibah R.G. 2014. Agricultural Production and Economic Growth in Nigeria: Implication for Rural Poverty Alleviation. Quarterly Journal of International Agriculture. 53(3). P. 207-223.

Phillip D., Nkonya E., Pender J., Ayoola Oni O. 2009. Constraints to Increasing Agricultural Productivity in Nigeria: A Review. Nigeria Strategy Support Program (NSSP). Background Paper No. NSSP 006. 64 p.

Thompson A. 2014. Multilateralism, Bilateralism and Regime Design. International Studies Quarterly. 58(1). P. 15-28. 